\title{
APLIKASI PENGELOLAAN PRESENSI GURU BERBASIS WEB DI DINAS PENDIDIKAN KABUPATEN BENGKALIS
}

\author{
Ratna Wulandari ${ }^{1}$, Danuri2, Jaroji3 \\ ${ }^{1,2,3}$ Teknik Informatika, Politeknik Negeri Bengkalis \\ 1ratnawulandari2109@gmail, ${ }^{2}$ danuri@polbeng.ac.id, ${ }^{3}$ jaroji@polbeng.ac.id
}

\begin{abstract}
Abstrak
Dinas pendidikan kabupaten bengkalis masih melakukan rekapitulasi data presensi sekolah secara manual. Untuk membuat rekapitulasi data presensi, setiap bulan pegawai sekolah harus mengantarkan data presensi ke kantor UPTD setempat, kemudian pegawai UPTD juga menyerahkan data tersebut ke kantor dinas pendidikan, sehingga proses pengiriman data presensi sekolah memakan waktu yang agak lama. Berdasarkan hal tersebut, maka dibutuhkan sebuah sistem untuk menerima proses pengiriman data presensi dengan cepat serta pengolahan dan rekapitulasi data presensi. Penelitian ini akan menghasilkan sistem presensi sekolah berbasis web yang dapat menerima data presensi dari finger print di masing masing sekolah, yang dilengkapi dengan pengolahan dan rekapitulasi data presensi sekolah dalam bentuk tabel dan grafik.
\end{abstract}

Kata kunci : Web, Rekapitulasi, Presensi

\section{Pendahuluan}

Perkembangan Teknologi di era globalisasi saat ini menjadi salah satu hal yang sangat berharga bagi instansi. Dengan pemanfaatan IT, akan membantu instansi tersebut dalam menangani informasi dalam jumlah besar. Setiap instansi memiliki kebijakan yang berbeda, sebagai contoh sebuah teknologi informasi presensi dan monitoring yang digunakan oleh instansi satu tidak dapat digunakan oleh instansi yang lainnya. Untuk itu, salah satu kegiatan penting yang harus instansi terapkan adalah pengolahan presensi dan pemantauan jam kerja karyawan yang baik agar kejelasan sistem dan pertanggung jawaban organ instansi dapat dikelola dengan benar.

Sebagai sebuah instansi, Dinas pendidikan kabupaten bengkalis memiliki peranan penting dalam melaksanakan urusan pemerintahan dibidang pendidikan, dan mengampu seluruh sekolah yang di kabupaten bengkalis. Salah satu tugas dinas pendidikan yaitu penerimaan data presensi dari sekolah - sekolah.

Berdasarkan informasi yang didapat, penerapan penerimaan data presensi guru di Dinas Pendidikan Kabupaten Bengkalis dilakukan dengan cara manual, yaitu tiap tiap sekolah menyerahkan presensi dalam bentuk laporan bulanan ke staf uptd yang akan diteruskan ke dinas pendidikan kabupaten Bengkalis. Kemudian staff uptd menginput laporan tiap tiap sekolah ke dalam file presensi dan membuat rekapitulasi presensi yang akan dikirimkan ke dinas pendidikan.

Pengolahan penerimaan data presensi secara manual salah satunya akan mengakibatkan keterlambatan penerimaan data, karena proses pengiriman yang akan memakan waktu. Keterlambatan pengiriman akan berpengaruh pada jalan nya arus sistem informasi yang lain seperti perekapan data presensi dalam memonitoring kinerja guru. Dari sisi keamanan, sistem presensi manual masih sangat rawan, apabila terjadi sobek atau hilang sehingga menyebabkan terlambatnya arus informasi presensi guru dalam merekap data.

Presensi karyawan adalah suatu kegiatan pencatatan terhadap setiap kehadiran karyawan dengan tujuan untuk mengetahui data yang berkaitan dengan kehadiran karyawan secara periodik baik harian maupun bulanan [1].

Kegiatan presensi yang berjalan selama ini masih menggunakan sistem manual, dengan cara mencatat kehadiran tenaga pendidikan dan pegawai di buku atau kertas presensi. Akibatnya kemungkinan terjadinya kesalahan ataupun hambatan dalam membuat rekapitulasi presensi menjadi besar. Kesalahan ataupun hambatan yang sering muncul antara lain hilangnya kertas atau daftar presensi. Salah satu cara untuk mengurangi kesalahan yang terjadi adalah dengan membuat sebuah sistem yang dapat digunakan di mana saja, dengan menggunakan satu database yang akan menyimpan data presensi sehingga kemungkinan data tercecer akan kecil. Selanjunya tentang pemanfaatan web service untuk presensi yang terintegrasi dengan alat fingerprint. Tujuan dari penelitian ini adalah untuk mengintegrasi sistem presensi finger print dengan menggunakan jaringan internet sehingga sistem bisa diakses dari jarak jauh [2]. 
Dari permasalahan diatas peneliti ingin membuat sebuah web yang dapat menerima data presensi dari finger print di masing masing sekolah yang dilengkapi dengan pengolahan dan rekapitulasi data presensi sekolah.

\section{Tinjauan Pustaka \\ 2.1 Kajian Terdahulu}

Penelitian yang terkait tentang pembangunan sistem informasi presensi yaitu penelitian web service for student attendance management system. Penelitian ini bertujuan untuk mengembangkan sistem manajemen informasi kehadiran mahasiswa untuk mengelola informasi kehadiran mahasiswa di setiap akedemi dan institute berbasis webservice (Pai dkk, 2016) .

Septiawan, dkk (2016) di dalam penelitiannya perancangan dan implementasi presensi digital guru dan karyawan SMA Negeri 9 Semarang. Penelitian ini menghasilkan sistem presensi berbasis web yang memiliki keunggulan dalam pengolahan data dan penyaijan informasi yang lebih cepat.

Efendi (2014) di dalam penelitiannya sistem presensi online berbasis web service dengan integrasi antara sistem sidik jari dan login $e$ learning. Penelitian ini menghasilkan presensi secara online dari data log fingerprint dan data login e-learning serta dapat menghasilkan laporan presensi. Penelitian ini menggunakan model pengembangan incremental yang merupukan perbaikan dari model waterfall.

Dewi, dkk (2014) di dalam penelitiannya aplikasi rekapitulasi elektronik absensi guru dan pegawai (Area - GP) pada sekolah menengah atas. Penelitian ini menghasilkan aplikasi rekapitulasi absensi guru dan pegawai secara elektronik yang dapat menyajikan informasi kinerja guru dan pegawai dengan tepat dan akurat.

Wibowo dan Santi (2012) didalam penelitian nya rekayasa database sekolah guna membangun presensi online berbasis bidik jari dan terintegerasi dengan perangkat pencetak idcard. Penelitian ini membangun sebuah sistem informasi yang dapat membuat database personal sekolah yang terdiri dari siswa, guru, dan karyawan tata usaha yang dapat menghitung (merekapitulasi) presensi kehadiran setiap saat yang terintegrasi dengan perangkat yang dapat mencetak kartu identitas sekolah, yang biasanya kartu identitas ini dimiliki oleh setiap siswa, guru, dan karyawan sekolah.

Armana (2012) di dalam penelitiannya perancangan dan implementasi untuk transfer data pada modul Harisma (Human Resource Management System). Penelitian ini menghasilkan sistem kepegawaian dan penggajian pegawai. Sistem Harisma terintegerasi dengan alat absensi dengan kartu barcode, finger print dan lain sebagainya..
Adapun penelitian di atas yang mendekati dengan penelitian penulis yaitu Armana (2012), septiawan (2016) yang menghasilkan sistem presensi berbasis web, dan Efendi (2014) yang menghasilakn presensi secara online dari data log fingerprint dan data login e-learning serta dapat menghasilkan laporan presensi. Perbedaan penelitian penulis dengan penelitian diatas ialah penelitian penulis hanya menghasilkan sistem presensi berbasis web yang mengambil data log fingerprint, dan tidak menggunakan e-learning. Sedangkan persamaan nya ialah penelitian diatas dan penulis sama sama menggunakan bahasa pemrograman PHP dan database MySQL.

\subsection{Landasan Teori}

\section{1) Presensi}

Presensi karyawan adalah suatu kegiatan pencatatan terhadap setiap kehadiran karyawan dengan tujuan untuk mengetahui data yang berkaitan dengan kehadiran karyawan secara periodik baik harian maupun bulanan (Rozikin dan Purwantini, 2014).

Presensi adalah pencatatan dan pengolahan data presensi yang dilakukan secara terus-menerus. Pencatatan dilakukan setiap hari kerja dan dilakukan pelaporan. Presensi pegawai merupakan salah satu tolak ukur metode pengembangan pegawai. Jika absensi pegawai setelah mengikuti pengembangan menurun, maka metode pengembangan yang dilakukan baik, sebaliknya jika absensi pegawai tetap berarti metode pengembangan yang diterapkan kurang baik. (Dewi dkk,2015).

\section{2) Rekapitulasi}

Pengertian rekapitulasi menurut Kamus Besar Bahasa Indonesia (KBBI) adalah 1. ringkasan, ikhtisar; 2. Ringkasan isi atau ikhtisar pada akhir laporan atau akhir hitungan; 3 . Pembuatan rincian data yang bercampur aduk menurut kelompok utama.

\section{3) Aplikasi}

Pengertian Aplikasi Menurut Kamus Besar Bahasa Indonesia (KBBI) adalah penerapan dari rancang sistem untuk mengolah data yang menggunakan aturan atau ketentuan bahasa pemrograman tertentu. Aplikasi adalah suatu program komputer yang dibuat untuk mengerjakan dan melaksanakan tugas khusus dari user (pengguna).

\section{4) Web}

World wide web atau sering dikenal sebagai web adalah suatu layanan sajian informasi yang menggunakan konsep hyperlink (tautan), yang memudahkan surfer (sebutan para pemakai komputer yang melakukan browsing atau 
penelusuran informasi melalui internet). Keistimewaan inilah yang telah menjadikan web sebagai service yang paling cepat pertumbuhannya. Web mengijinkan pemberian highlight (penyorotan atau penggaris bawahan) pada kata kata atau gambar dalam sebuah dokumen untuk menghubungkan atau merujuk ke media lain seperti dokumen, frase, movie clip atau file suara. Web dapat menghubungkan dari sembarangan tempat dalam sebuah dokumen atau gambar ke sembarang tempat di dokumen lain. Dengan sebuah browser yang memiliki Graphical User Interface (GUI), link link dapat di hubungkan ke tujuannya dengan menunjuk link tersebut dengan mouse dan menekannya (Palit dkk, 2015).

\section{5) PhpMyAdmin}

PHPMyAdmin adalah perangkat lunak yang bebas ditulis dalam bahasa pemrograman PHP yang digunakan untuk menangani administrasi MySQL melalui jejaring jagat jembar (World Wide Web). PHPMyAdmin mendukung berbagai operasi MySQL, diantaranya (mengolah basis data, table table, bidang (fields), relasi (relation), indeks, pengguna (users), perjanjian (permission) dan lainlain) (Rozaq dkk, 2015).

\section{6) $P H P$}

PHP adalah bahasa pemrograman yang digunakan secara luas untuk penanganan pembuatan dan pengembangan sebuah web dan biasa digunakan pada HTML. PHP merupakan singkatan dari "PHP : Hypertext Preprocessor", dan merupakan bahasa yang disertakan dalam dokumen HTML, sekaligus bekerja di sisi server (server-side HTML-embedded scripting). Artinya sintaks dan perintah yang diberikan akan sepenuhnya dijalankan di server tetapi disertakan pada halaman HTML biasa, sehingga script-nya tak Nampak disisi client.

PHP dirancangan untuk dapat bekerja sama dengan database server dan dibuat sedemikian rupa sehingga pembuatan dokumen HTML yang dapat mengakses database menjadi bagitu mudah. Tujuan dari bahasa scripting ini adalah untuk membuat aplikasi dimana aplikasi tersebut yang dibangun oleh PHP pada umumnya akan memberikan hasil pada web browser, tetapi prosesnya secara keseluruhan di jalankan di server (Palit dkk, 2015).

\section{7) $\quad X A M P P$}

XAMPP adalah aplikasi yang berfungsi sebagai server yang berdiri sendiri (localhost), yang terdiri beberapa program antara lain : Apache HTTP Server, MySQL database dan penerjemah bahasa yang ditulis dengan bahasa pemrograman PHP dan Perl (Jamil dan Banyumin, 2015).

8) $U M L$

Menurut Dharwiyanti dan Wahono (2003) Unified Modelling Language (UML) adalah sebuah bahasa yang telah menjadi standar dalam industri untuk visualisasi, merancang dan mendokumentasikan sistem piranti lunak. UML mendefinisikan diagram-diagram seperti : use case diagram, class diagram, statechart diagram, activity diagram, sequence diagram, collaboration diagram, component diagram dan deployment diagram .

9) $E R D$

ERD adalah model konseptual yang mendeskripsikan hubungan antar penyimpanan dalam DFD. ERD digunakan untuk memodelkan struktur data dan hubungan antar data. Dengan ERD model dapat diuji dengan mengabaikan proses yang harus dilakukan. Selain itu dengan ERD kita akan dapat menjawab pertanyaan mengenai data apa yang kita perlukan serta bagaimana data yang satu berhubungan dengan data yang lain (Ivananda dkk, 2015).

\section{Perancangan \\ 3.1 Sistem yang dibangun di Dinas Pendidikan Kabupaten Bengkalis}

Analisa sistem aplikasi presensi ini menjelaskan bahwa admin UPTD memberikan hak akses kepada TU sekolah berupa kode aktivasi untuk bisa mengirimkan data presensi ke web server yang ada di UPTD, kemudian data yang ada pada web tersebut akan diolah oleh admin UPTD, data hasil olahan berupa rekapitulasi presensi, data sanksi kehadiran dan grafik, dapat diakses oleh TU sekolah, kepala sekolah dan dinas.

Proses sistem kerja web server ini saling terhubung atau tersinkronisasi dengan data yang ada pada database lokal sekolah. Untuk mengirim data presensi ke web server UPTD, TU sekolah harus mengirim data melalui internet. Aplikasi pengelolaan presensi berbasis web berguna untuk melakukan pencatatan kehadiran guru sekolah, melihat rekapitulasi, melihat data sanksi kehadiran dan melihat grafik presensi. Data hasil olahan. Analisa sistem yang akan dibangun akan disajikan pada Gambar 5.

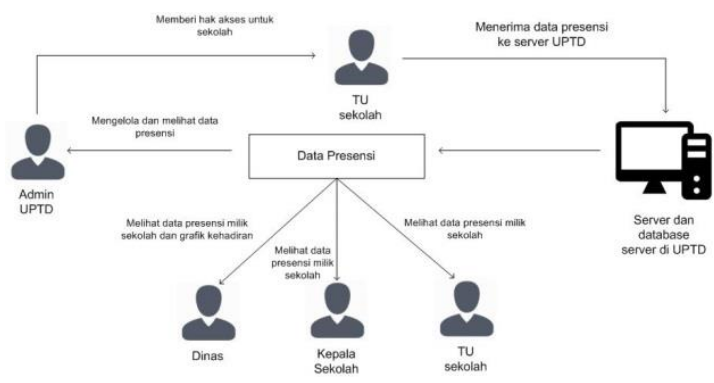

Gambar 1. Analisa sistem yang akan dibangun (Sumber : Data Olahan) 


\subsection{Sistem yang dibangun di Dinas Pendidikan Kabupaten Bengkalis}

Agar penelitian yang dilakukan lebih terarah maka langkah - langkah yang harus dilakukan didalam prosedur penelitian dimulai dengan mengindentifikasi asalah masalah yaitu sebagai berikut:

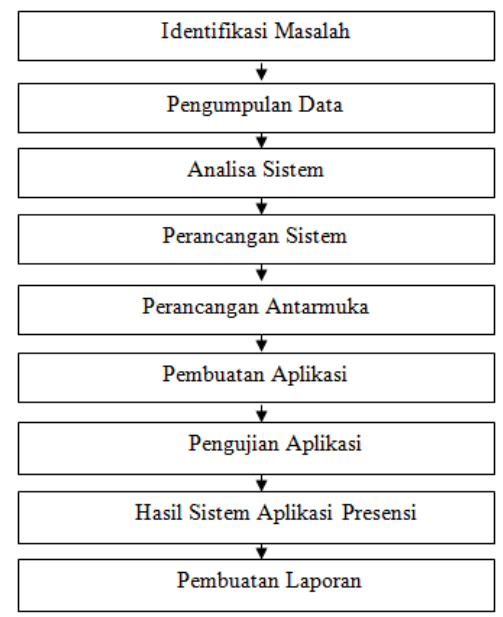

Gambar 2. Prosedur Penelitian (Sumber : Data Olahan)

\section{Hasil dan Pengujian 4.1 Hasil}

Adapun hasil yang diperoleh pada penelitian ini yaitu aplikasi engelolaan presensi guru berbasis web di Dinas Pendidikan Kabupaten Bengkalis. Merupakan aplikasi pengelolan presensi guru di sekolah yang dapat di pantau oleh TU sekolah, kepala sekolah dan dinas pendidikan. Pada sistem ini, untuk proses terima data presensi dari sekolah, admin UPTD memberikan hak akses kepada sekolah berupa kode aktivasi untuk melakukan pengiriman data absen melalui web sekolah ke web pengelolaan presensi guru yang ada di UPTD. Kemudian data presensi tersebut akan di olah menjadi rekap dan grafik kehadiran. Berikut tampilan login, presensi, rekap dan grafik kehadiran dapat dilihat pada Gambar 3,4, 5 dan 6.

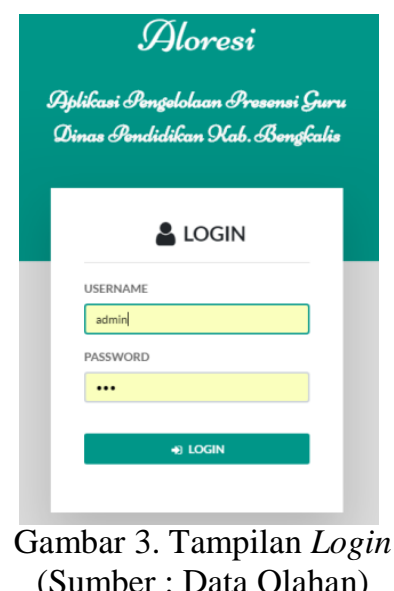

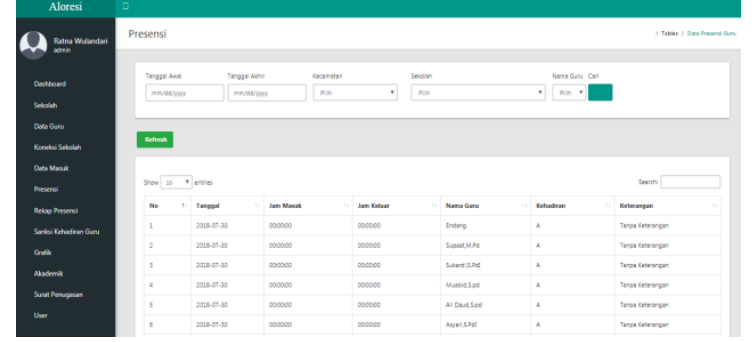

Gambar 4 Tampilan Presensi (Sumber : Data Olahan)

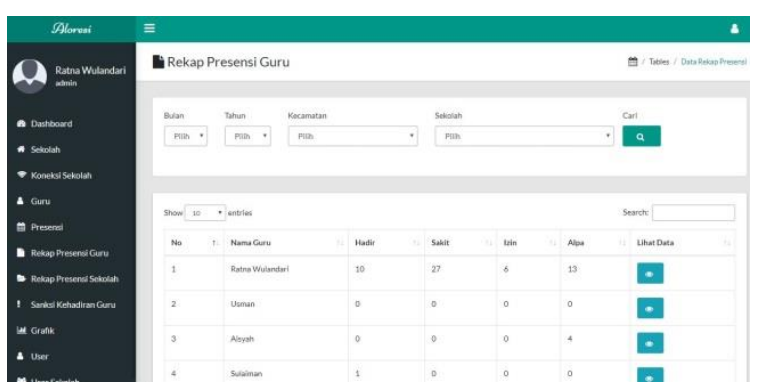

Gambar 5. Tampilan Rekap (Sumber : Data Olahan)

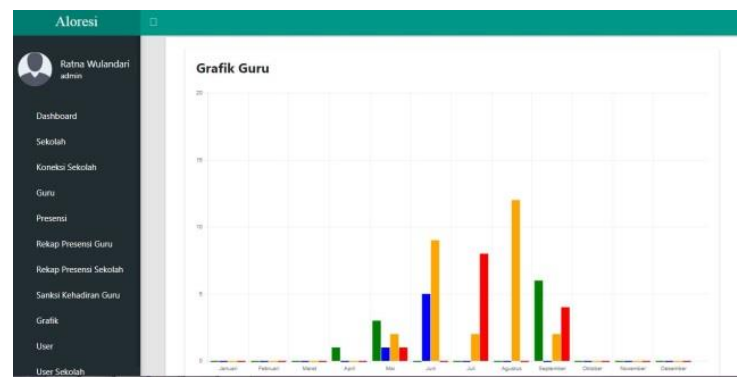

Gambar 6. Tampilan Grafik

(Sumber : Data Olahan)

\subsection{Pengujian}

1) Pengujian Sistem

Pengujian ini dilakukan untuk mengetahui tingkat keberhasilan tugas akhir yang telah direncanakan seperti bab perancangan. Selain itu dengan adanya pengujian dapat diketahui adanya kelemahan atau kekurangan yang ada pada tugas akhir ini. Dari hasil uji coba yang telah dilakukan dianalisa apakah rancangan ini dapat memenuhi tujuan yang akan dicapai seperti yang telah dipaparkan pada Bab I.

\section{2) Pengujian Proses}

Pengujian proses adalah pengujian yang dilakukan untuk mengetahui tingkat keberhasilan dari semua proses proses yang terjadi atau yang dapat dilakukan sistem yang telah dibangun, meliputi input dan output.
a. Pengujian Proses Admin
Pengujian proses admin merupakan semua proses-proses yang dapat dilakukan pada sisi 
administrator. Adapun proses-proses yang dapat dilakukan pada sisi admin dapat dilihat seperti pada tabel 1 .

Tabel 1. Pengujian Proses Admin

\begin{tabular}{|c|c|c|c|}
\hline \multirow{2}{*}{ No } & \multirow{2}{*}{$\begin{array}{l}\text { Item Pengujian } \\
\text { Input/Output }\end{array}$} & \multicolumn{2}{|c|}{ Hasil } \\
\hline & & Berhasil & Gagal \\
\hline 1 & Login admin & $\checkmark$ & - \\
\hline 2 & $\begin{array}{l}\text { Menambah dan } \\
\text { mengelola akun baru } \\
\text { untuk user }\end{array}$ & $\checkmark$ & - \\
\hline 3 & $\begin{array}{lr}\text { Menambah } & \text { dan } \\
\text { mengelola } & \text { kode } \\
\text { aktivasi untuk sekolah }\end{array}$ & $\checkmark$ & - \\
\hline 4 & $\begin{array}{ll}\text { Menambah } & \text { dan } \\
\text { mengelola } & \text { data } \\
\text { sekolah } & \end{array}$ & $\checkmark$ & - \\
\hline 5 & $\begin{array}{l}\text { Menambah dan } \\
\text { mengelola data guru }\end{array}$ & $\checkmark$ & - \\
\hline 6 & $\begin{array}{ll}\text { Mengelola } & \text { data } \\
\text { presensi masuk dan } \\
\text { presensi keluar }\end{array}$ & $\checkmark$ & - \\
\hline 7 & $\begin{array}{l}\text { Melihat rekap presensi } \\
\text { perbulan untuk guru }\end{array}$ & $\checkmark$ & - \\
\hline 8 & $\begin{array}{l}\text { Melihat rekap presensi } \\
\text { perbulan } \\
\text { sekolah }\end{array}$ & $\checkmark$ & - \\
\hline 9 & $\begin{array}{l}\text { Melihat rekap data } \\
\text { sanksi kehadiran guru } \\
\text { perbulan }\end{array}$ & $\checkmark$ & - \\
\hline 10 & $\begin{array}{ll}\text { Melihat } & \text { grafik } \\
\text { presensi guru }\end{array}$ & $\checkmark$ & - \\
\hline 11 & $\begin{array}{l}\text { Melihat grafik } \\
\text { presensi sekolah }\end{array}$ & $\checkmark$ & - \\
\hline 12 & $\begin{array}{l}\text { Melihat grafik } \\
\text { presensi UPTD }\end{array}$ & $\checkmark$ & - \\
\hline 13 & $\begin{array}{l}\text { Membuat agenda } \\
\text { kalender akademik }\end{array}$ & $\checkmark$ & - \\
\hline 14 & $\begin{array}{lr}\text { Menambah } & \text { dan } \\
\text { mengelola } & \text { Surat } \\
\text { Penugasan } & \end{array}$ & $\checkmark$ & - \\
\hline
\end{tabular}

b. Pengujian Proses User

Pengujian proses admin merupakan semua proses-proses yang dapat dilakukan pada sisi user yaitu, TU sekolah, kepala sekolah dan dinas. Adapun proses-proses yang dapat dilakukan pada sisi user dapat dilihat seperti pada tabel 2.

Tabel 2. Pengujian Proses User

\begin{tabular}{|c|l|c|c|}
\hline \multirow{2}{*}{ No } & \multirow{2}{*}{$\begin{array}{l}\text { Item Pengujian } \\
\text { Input/Output }\end{array}$} & \multicolumn{2}{|c|}{ Hasil } \\
\cline { 2 - 4 } & TU sekolah & Berhasil & Gagal \\
\hline 1 & TU & \\
\hline \multirow{2}{*}{} & Login aplikasi & $\checkmark$ & - \\
\cline { 2 - 4 } & Melihat data guru & $\checkmark$ & - \\
\cline { 2 - 4 } & $\begin{array}{l}\text { Melihat data } \\
\text { presensi }\end{array}$ & $\checkmark$ & - \\
\hline
\end{tabular}

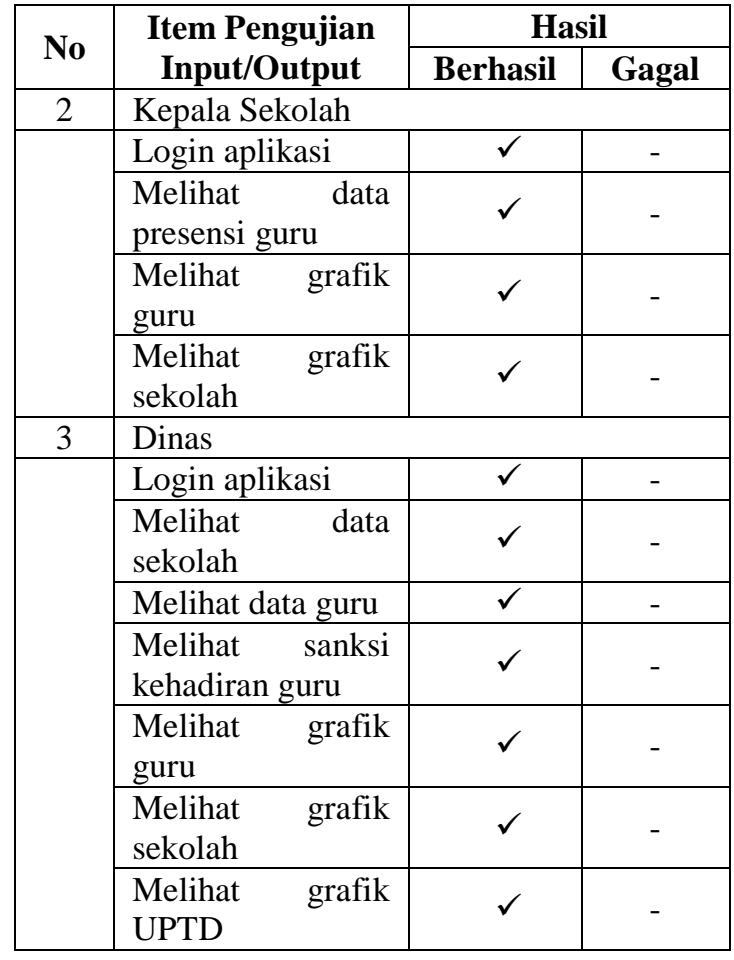

\section{c. Pengujian Proses Kirim Terima Data}

Pengujian proses kirim terima data merupakan semua proses-proses kirim terima data yang dilakukan oleh web pengelolaan presensi terhadap web yang ada disekolah. Adapun prosesproses yang dapat dilakukan oleh web pengelolaan presensi dapat dilihat seperti pada tabel 3.

Tabel 3. Pengujian Proses Kirim Terima Data

\begin{tabular}{|c|l|c|c|}
\hline \multirow{2}{*}{$\begin{array}{c}\text { N } \\
\mathbf{o}\end{array}$} & \multirow{2}{*}{ Item Pengujian } & \multicolumn{2}{|c|}{ Hasil } \\
\cline { 3 - 4 } & Berhasil & Gagal \\
\hline 1 & Sinkron data sekolah & $\checkmark$ & - \\
\hline 2 & Sinkron data golongan & $\checkmark$ & - \\
\hline 3 & Sinkron data jabatan & $\checkmark$ & - \\
\hline 4 & $\begin{array}{l}\text { Sinkron data status } \\
\text { pegawai }\end{array}$ & $\checkmark$ & - \\
\hline 5 & Sinkron data guru & $\checkmark$ & - \\
\hline 6 & Sinkron data presensi & $\checkmark$ & - \\
\hline
\end{tabular}

\section{d. Pengujian pada Webbrowser}

Pengujian aplikasi pada webbrowser dilakukan pada beberapa webbrowser yaitu Google Chrome dan Mozilla Firefox. Pengujian dilakukan untuk mengetahui keberhasilan program. Pengujian pada webbrowser dapat dilihat seperti pada tabel 4 .

Tabel 4. Pengujian pada Webbrowser

\begin{tabular}{|c|l|c|c|}
\hline \multirow{2}{*}{ No } & \multirow{2}{*}{ Item Pengujian } & \multicolumn{2}{|c|}{ Hasil } \\
\cline { 3 - 4 } & & Berhasil & Gagal \\
\hline 1 & Google Chrome & $\checkmark$ & - \\
\hline 2 & Mozilla Firefox & $\checkmark$ & - \\
\hline
\end{tabular}




\section{Kesimpulan dan Saran}

Adapun kesimpulan yang didapat setelah melakukan penelitian ini adalah sebagai berikut :

1. Sistem pengelolaan presensi ini mampu menghitung data kehadiran guru.

2. Sistem pengelolaan presensi ini mampu mengelola data kehadiran guru dan menyediakan laporan dalam bentuk tabel dan grafik kehadiran.

Adapun saran yang dapat dikembangkan setelah melakukan pengujian aplikasi adalah sebagai berikut:

1. Pada penelitian ini, menggunakan asumsi penggunaan prosedur standar presensi sehingga perlu penyesuaian lagi jika mempunyai kondisi lain selain presensi masuk dan keluar.

2. Sistem masih menggunakan notifikasi standar sebagai pemberitahuan bahwa ada data yang masuk, sehingga perlu adanya pengembangan untuk menghasilkan notifikasi realtime sebagai pemberitahuan.

\section{Daftar Pustaka :}

Armana, I., 2012, Perancangan Dan Implementasi Web Service Untuk Transfer Data Pada Modul Harisma (Human Resource Manangement System), Jurnal Elektronik Ilmu Komputer, (1), 2.

Dewi, M., Anggraeni, V.D., Mudjadi, S.A., dan Wicaksono, A., 2014, Aplikasi Rekapitulasi Elektronik Absensi Guru \& Pegawai (Area-Gp) Pada Sekolah Menengah Atas, Seminar Nasional Teknologi Informasi dan Komunikasi 2014 (SENTIKA 2014).

Dewi, Rodhiyana., Hasanah, P., dan Rohmatulloh., 2015, Perancangan dan Implementasi Sistem Presensi Berbasis Finger Print di SMPN 1 Tanjunganom, e-Proceeding of Applied Science, (2), 1, 2442-5826.

Dharwiyanti, S., dan Wahono, R.S., 2003, Pengantar Unified Modeling Language (UML), Modul Kuliah Umum Ilmu Komputer.

Efendi, U., 2014, Sistem Presensi Online Berbasis Web Service dengan Integerasi antara sistem sidik jari dan login e-learning, Program Studi Sistem Informasi Universitas Jember, Jember.

Haviluddin, 2011, Memahami Penggunaan UML, Jurnal Informatika Mulawarman , (1), 6.

Hendini, A., 2016, Pemodelan UML Sistem Informasi Monitoring Penjualan dan Stok Barang (Studi Kasus : Distro Zhezha Pontianak), Jurnal Khatulistiwa Informatika , (2), 4.

Ivananda, F., Samaji, I., dan Yanuar, T., 2015, Aplikasi Perhitungan Pendapatan dan Perhitungan Pajak Kereta Api Berbasis Web, $e$ Proceeding of Applied Science , (3), 1, 24425826
Jamil, M., dan Bunyamin, 2015, Pengembangan Aplikasi Sistem Informasi Laporankeuangan Walisantri Di Pondok Pesanren, Jurnal Algoritma , (12), 1, 2302-7339.

Pai, A., V., Krishna, A., Kshama., Corres, M., 2016 Web Services for student attendance management system, International Journal of Advance Research in Science and engineering, (5),3.

Palit, R.V., Rindengan, Y.D.Y., Lumentas, A.S.M., 2015, Rancangan Sistem Informasi Keuangan Gereja Berbasis Web Di Jemaat GMIM Bukit Moria Malalayang, E-Journal Teknik Elektro dan Komputer, (4), 7, 2301-8402.

Rozaq, A., Lestari, K.F., Handayani, S., 2015, Sistem Informasi Produk Dan Data Calon Jamaah Haji Dan Umroh Pada Pt. Travellindo Lusiyana Banjarmasin Berbasis Web,Jurnal POSITIF , (1), 1, 1-13.

Rozikin, K., Purwantini, K., 2014 Pengaruh Sistem Presensi dengan Deteksi Sidik Jari dan SMS Gateway Terhadap Tingkat Membolos Siswa, Seminar Nasional Teknologi Informasi \& Komunikasi Terapan 2014(Semantik 2014).

Septiawan, D., Kridalukmana, R., Windasari, I., P., 2016 Perancangan dan Implementasi Presensi Digital Guru dan Karyawan SMA Negeri 9 Semarang, Jurnal Teknologi dan Sistem Komputer, (2), 4.

Wibowo, J., S., dan Santi, R., C., N., 2012 Rekayasa Database Sekolah Guna Pembangunan Presensi Online Berbasis Sidik Jari dan Terintegerasi dengan Perangkat Cetak Id Card Universitas Stikubank Semarang, 2012. 